\begin{tabular}{|lc|}
\hline JU2RINAU & Jurnal Pendidikan Vokasi \\
PENDIDIKAN & Volume 10, No.2,2020(188-202) \\
VOKASI & Online: http://journal.uny.ac.id/index.php/jpv \\
\hline
\end{tabular}

\title{
MODEL OF ESSENTIAL EMPLOYABILITY SKILLS FRAMEWORK FOR MACHINE OPERATOR
}

\author{
Hari Din Nugraha $^{1 *}$, Deny Poniman Kosasih ${ }^{1}$, Kasda $^{1}$, As'ari Djohar ${ }^{2}$, Mumu Komaro $^{2}$ \\ ${ }^{1}$ Universitas Subang \\ Jl. Arif Rahman Hakim No. 8, Subang, Jawa Barat 41211, Indonesia \\ ${ }^{2}$ Universitas Pendidikan Indonesia \\ J1. Dr. Setiabudi No. 227, Gegerkalong, Sukasari, Kota Bandung, Jawa Barat 40153, Indonesia
}

\begin{abstract}
Employability skills are the skills that a person must have to get a job, stay in work, and be able to achieve success in their career. This study aims to develop a model of specific employability skills framework for machine operators. The research design used is the mixed methods, a study that combines the quantitative and qualitative methods and convergent parallel strategy in the data mixing process. The research finding is 14 identified frameworks of employability skills, including (1) basic skills: communicating, listening; (2) self-quality: attendance, collaboration, responsibility, honesty, flexibility, empathy; (3) thinking skills: creativeness, problem-solving; (4) management: self-management, planning; (5) system and technology: production flow system, and mastery of job field concept. Industries demand that basic skills have to be possessed by machine operators to be and self-quality as the priority to recruited as prospective skilled workers. Thinking skills, management, and system and technology are better if developed in their future workplace.
\end{abstract}

Keywords: employability skills, framework, machine operators

How to cite: Nugraha, H., Kosasih, D., Kasda, K., Djohar, A., \& Komaro, M. (2020). Model of essential employability skills framework for machine operator. Jurnal Pendidikan Vokasi, 10(2), 188-202. doi:https://doi.org/10.21831/jpv.v10i2.31869

*Corresponding Author: Hari Din Nugraha - haridinnugraha@unsub.ac.id

- Department of Mechanical Engineering, Faculty of Engineering, Universitas Subang

Jl. Arif Rahman Hakim No. 8, Subang, Jawa Barat 41211, Indonesia 


\section{INTRODUCTION}

The needs for employability skills are very important in order to prepare school graduates to enter the labor market. Employability skills refer to the skills needed to manage attitude, behavior, and academic competence needed by industries (Husain et al., 2010) so that school graduates are prepared to compete in the labor market and have the opportunity to become labor candidates who are ready to be recruited by industries (Ismail \& Mohammed, 2015; Sisodia \& Agarwal, 2017).

Industrial Revolution 4.0 requires responses to every change in the job market. The climate of the changing labor market needs is directly proportional to the changing skills needs of the workforce, and it has implication in the employability needs that must be updated in accordance with the demands of the labor market needs (Bukit, 2014; Wibawa, 2005; Zaharim et al., 2009). The rapid change of skill needs is caused by the transition process of the industrial economy to knowledge economy, which has effects on the demand and competition of skilled labor.

The competition that will be faced by prospective Indonesian workers is not only regional but also global. Indonesia is faced with APEC (Asian Pacific Economic Corporation) free trade in 2020 so that it becomes an opportunity and challenge for developing countries like Indonesia. Indonesia has a good opportunity because of its fast population growth, where, in 2025, Indonesia will get a demographic bonus with a large population of productive age compared to the population of non-productive age (Tjiptoherijanto, 2001).

On the other hand, the high demographic bonus by having a productive age of Indonesia's population must be accompanied by an increase in human resources quality because this country has a ratio of labor to a population of $64.17 \%$ with an unemployment rate of $4.18 \%$ (International Labour Organization, 2018). This figure is relatively high compared to that of Southeast Asian countries such as Vietnam, the Philippines, and Myanmar, which is relatively smaller. It becomes a challenge to prepare skilled labor.

Research findings show that the skills that workers must have to support job security are the skills to develop new innovative, creative ideas, ability to analyze problems, and interpersonal communication with colleagues and clients (Nair et al., 2009; Wickramasinghe \& Perera, 2010; Yang et al., 2015). In addition, self-managerial skills are considered one of the most important indicators needed by many industries (Sermsuk et al., 2014). Those skills are badly needed because they have an effect on more advanced companies (de Guzman \& Choi, 2013).

In more detail, machine operators are at level 2 in the Indonesian Qualification Framework (IQF). Machine operators must have a standard, in which there is mechanical engineering expertise skill, which has the following competencies: (1) applying the K3 principles in the workplace, (2) applying quality procedure, (3) measuring using a measuring instrument, (4) operating general machinery, (5) using manual equipment, (6) reading technical drawing, (7) operating a lathe, (8) operating the milling machine and setting the machine and its program NC/CNC (9) operating and observing machines, and (10) operating machines NC/CNC (National Professional Certification Agency, 2017).

Facts show that many school graduates do not have employability skills in the workplace (Wei Chan et al., 2018). Operators tend to find it difficult to manage time, be less responsible, and not have a positive attitude to sustainable learning. All those hamper production processes in companies (Stoner \& Milner, 2010). Besides, the researchers found reality in the field during preresearch interviews with a manager that shows that machine operators did not have good communication skills, which resulted in mistakes in receiving information and a tendency to be passive, which also hampers their work. This impacts the mismatch between industrial needs and graduates' skills.

One of the employability skills that must be possessed by prospective machine operators is the skill to meet labor market needs. Therefore, skillful machine operators can be employed and stay in work in metal and machine manufacturing industries (Rowley, 2014). Thus, employability skills should always be close and hand in hand with the labor market. Based on this rationale, theoretically, employability skills are suitable for workers in various fields such as various technical fields (McLean et al., 2013; Stoner \& Milner, 2010). However, in the specific field, machine operators' jobs must vary. For this reason, further research is needed to discover the needs of essential employability skills suitable to be applied by machine operators. 
This research aims to survey essential employability skills needed by machine operators whose orientation is manufacturing industries of metal and machinery. As instructional steps, it identifies and verifies industries to find indicators of employability skills considered important and strategic for the profile of machine operators so that the graduates of mechanical engineering vocational high schools (VHS) can be absorbed more by manufacturing industries of metal and machinery. The result of this research is expected to be a recommended framework as practical anticipatory steps in making the programs of mechanical engineering VHS. In addition, this research's finding becomes a reference and helps industries evaluate their performance in improving their work quality according to the dynamic environment and becomes a recommendation for companies when they recruit new machine operators.

\section{RESEARCH METHOD}

The method used in this research is a mixed-method - a method that combines the quantitative and qualitative methods. The convergent parallel strategy design combines both types of data separately and makes interpretations in order to reveal whether there is a convergence or divergence (Creswell, 2009). Furthermore, the findings are analyzed to see whether or not they mutually inform. In this research, the different sample size or weight is not a problem, but it is for getting an in-depth perspective to generalize the population. In addition, the quantitative result is reported first, followed by the qualitative one to confirm and compare them in the discussion (see Figure 1).

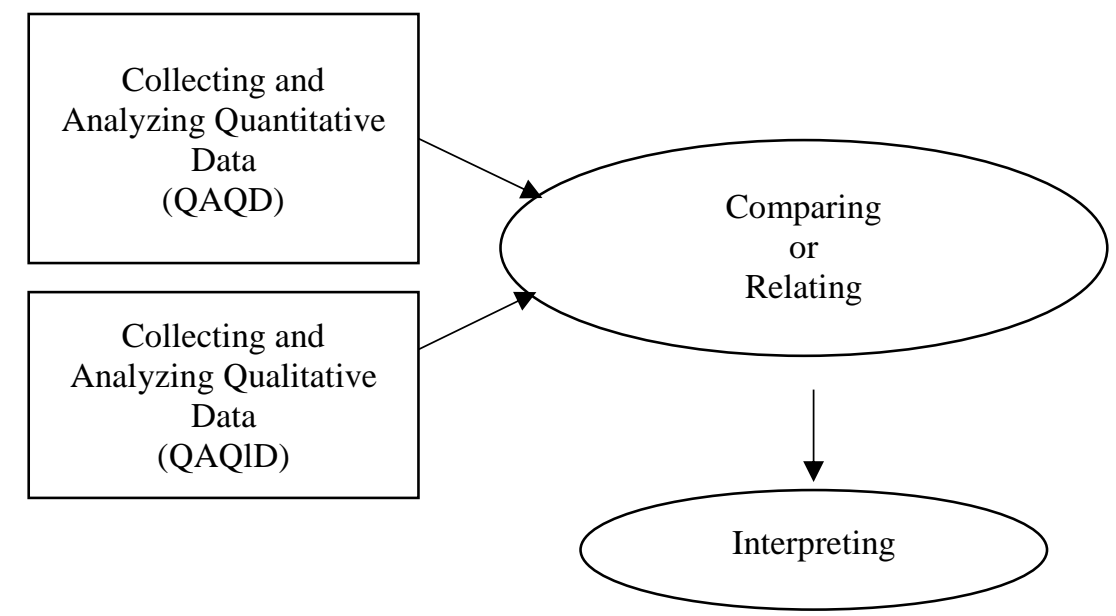

Figure 1. Convergent Parallel Design

This research population is manufacturing industries of metal and machinery situated in the provinces of Jakarta Special Capital Territory, Banten, and West Java. The sampling technique used is based on convenience and availability in the field (Babbie, 2007). The research sample is 69 industries engaged in metal and machinery, with 98 respondents consisting of 69 machine operators, 19 team leaders, eight supervisors, and two managers.

This research uses an online questionnaire and structured interviews for collecting the data. The questionnaire contains statements with checklist $(\sqrt{ })$ at the statement point in accordance with respondents' responses. The instrument for the survey was developed from the indicators of research findings on employability skills. It was adopted from SCANS (The Secretary Commission on Achieving Necessary Skills) which was adapted to the needs of machine operators' work.

The validation of the questioner was done through expert judgment by comparing the suitability among indicators and instrument grids. The reliability measures were done to see the consistency of the research instrument. The rubric developed in this research consists of 42 test items including all indicators measured from the aspects of basic skill, thinking skill, self-quality, human resource management, interpersonal skill, information and system management, and technology. The scoring criterion is a score of four for the highest score and a score of one for the lowest score. 
The statistical and inferential analysis is presented in tables of contribution and diagrams. Then, a parallel convergent strategy was carried out by analyzing the result of the two groups of data separately and by making interpretation to see whether or not there was a convergence or divergence. After that, a decision was made in the form of the suggested framework of the quantitative and qualitative findings for machine operators.

\section{RESULTS AND DISCUSSION}

The finding was obtained from respondents after the analysis of quantitative data collected through a survey and qualitative data through interviews. The result of the survey is divided into two parts. The first part contains questions related to demography, and the second part contains 42 close questions. The quantitative analysis presented the data on respondent profiles, descriptive analysis, and ranks of importance. The findings of this research are presented as follows.

Figure 2 shows the respondents' demography. The result of the analysis shows that the educational background of the workers is different from one another. This becomes a variation of its own with various educational backgrounds of the workers. The respondents' profile is classified into four levels of education: high school, diploma 3, bachelor/diploma 4, and masters. Figure 2 shows that most of the sample respondents are high school graduates, with a percentage of $45.92 \%$, followed by diploma 3 graduates, as many as $29.60 \%$. As many as $23.46 \%$ of the respondents are bachelor degree holders, and the rest $1.02 \%$ hold a master degree.

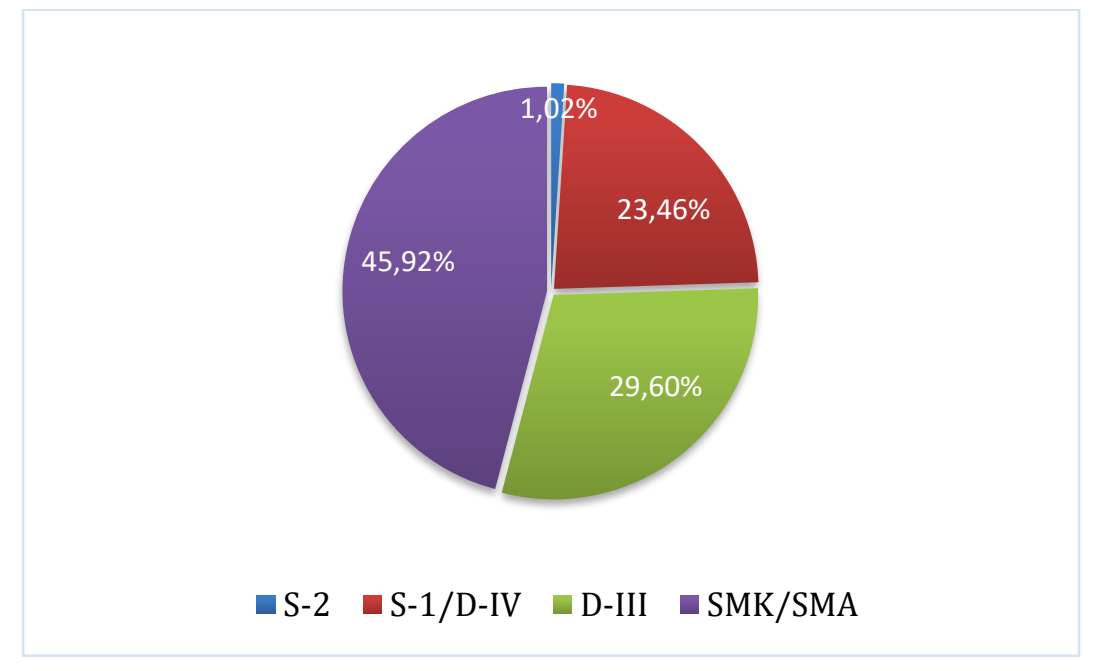

Figure 2. Demography of Respondents

Table 1 presents the result of the quantitative analysis of machine operators' perception of employability skills priority. Machine operators consider that the most essential employability skills needed by an operator in order to achieve top career in the workplace is basic skills with the indicator of careful reading in the workplace, and gave it the highest score $(\mathrm{M}=3.87)$. Following that, machine operators consider thinking skills of "completing work in a shorter time than the specified one" is the skill considered not important, and gave it the lowest score (M=3.10).

The results of the questionnaire and interviews were compared in order to have a really essential result by using the parallel convergent technique, which can compare results to see whether or not the findings mutually confirm. The process of combining the qualitative and quantitative data disregarded respondents' scores but focused on in-depth perspective to generalize population. Furthermore, interpretation was done by selecting the indicators which had convergence, and the divergent indicators were not selected and supported by relevant theories. The results that showed similarities and intersect, between the quantitative and qualitative results, were then selected and used further as a recommendation for the employability skills framework. The framework in Figure 3 was developed applying the theory of Robinson and SCANS. This interpretation stage resulted in 14 essential employability skills most needed by manufacturing industries of metal and machinery. 
192 - Hari Din Nugraha, Deny Poniman Kosasih, Kasda, As'ari Djohar, \& Mumu Komaro

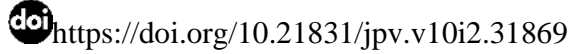

Table 1. Perception of the Importance Level of Employability Skills

\begin{tabular}{|c|c|c|c|}
\hline Rank & Employability skills & $\mathbf{M}$ & SD \\
\hline 1 & Reading the rules that apply in workplace & 3.87 & 0.35 \\
\hline 2 & Reading the Standard Operasional Prosedur (SOP) on machines & 3.83 & 0.38 \\
\hline 3 & Reading job description & 3.83 & 0.38 \\
\hline 4 & Listening to instructions from team leader of machine operators & 3.80 & 0.41 \\
\hline 5 & Discipline in punctuality & 3.80 & 0.41 \\
\hline 6 & Behaving honestly in working & 3.77 & 0.50 \\
\hline 7 & Showing good ethics in working & 3.70 & 0.47 \\
\hline 8 & Maintaining attendance level in the company & 3.70 & 0.47 \\
\hline 9 & Being responsible for product quality according to the standard & 3.67 & 0.48 \\
\hline 10 & Team-working with colleagues & 3.67 & 0.48 \\
\hline 11 & Conveying verbal informasion clearly in accordance with job needs & 3.67 & 0.48 \\
\hline 12 & Showing good work ethos in working & 3.63 & 0.56 \\
\hline 13 & Helping colleagues having difficulties doing their work & 3.60 & 0.50 \\
\hline 14 & Using safety equipment (safety shoes, wearpack, and spectacles) when working & 3.57 & 0.50 \\
\hline 15 & Determining quick work procedure & 3.57 & 0.50 \\
\hline 16 & Informing job progress to new machine operators at the shift changing & 3.53 & 0.57 \\
\hline 17 & Maintaining the cleanliness of the workshop area & 3.53 & 0.51 \\
\hline 18 & Identifying hazard potential in the workshop & 3.53 & 0.51 \\
\hline 19 & Reading the table of speed on machine parameter & 3.50 & 0.51 \\
\hline 20 & Working according to production target & 3.50 & 0.51 \\
\hline 21 & Selecting cutting tools with specification suitable with operational needs & 3.47 & 0.51 \\
\hline 22 & Reading mechanical engineering figure & 3.47 & 0.57 \\
\hline 23 & Doing the maintenance of inventary tools used in machines & 3.47 & 0.51 \\
\hline 24 & $\begin{array}{l}\text { Understanding Numeric Controlled program information in the system to be } \\
\text { operated in machines according to procedure }\end{array}$ & 3.47 & 0.51 \\
\hline 25 & Streamlining raw materials to be more economical & 3.43 & 0.57 \\
\hline 26 & $\begin{array}{l}\text { Understanding production flow system from raw materials-production process- } \\
\text { quality control }\end{array}$ & 3.43 & 0.50 \\
\hline 27 & Identifying trouble shooting in machines & 3.40 & 0.50 \\
\hline 28 & Accepting team leader's criticism well & 3.40 & 0.56 \\
\hline 29 & Working according to the planned schedule & 3.40 & 0.50 \\
\hline 30 & Reading measurement result of precise mechanic measuring device & 3.40 & 0.50 \\
\hline 31 & Adapting working method to the change of working environment & 3.37 & 0.56 \\
\hline 32 & Doing the maintenance on the machine used in work & 3.37 & 0.49 \\
\hline 33 & Selecting machines according to operational needs specification & 3.33 & 0.55 \\
\hline 34 & Writing daily work reports & 3.30 & 0.47 \\
\hline 35 & Carrying out machine operation & 3.30 & 0.53 \\
\hline 36 & Reporting all accidents that have happened & 3.23 & 0.43 \\
\hline 37 & Controlling production processes & 3.23 & 0.57 \\
\hline 38 & Calculating machining process parameters & 3.17 & 0.46 \\
\hline 39 & Working independently & 3.17 & 0.53 \\
\hline 40 & Understanding company's organization bureaucratic structure & 3.13 & 0.57 \\
\hline 41 & $\begin{array}{l}\text { Setting machine programs (numerical controlled }=\mathrm{NC}) /(\text { computer numerically } \\
\text { controlled }=\mathrm{CNC})\end{array}$ & 3.13 & 0.68 \\
\hline 42 & Completing work in a shorter time than the specified one & 3.10 & 0.80 \\
\hline
\end{tabular}


The criteria of employability skills that must be possessed by a machine operator specifically contains 14 working skills. The industries prioritize good personality or generic skills over performance. Machine operators, in fulfilling the labor market, are prioritized to have the most dominant self-quality and basic skills. They have to pass the standard test that is required by the companies, such as the psycho-test, health, and also interviews. They must also master the basic competence in manufacturing work concept, so that when they work in a company, their employers will not find it difficult to improve their hard skills through the pre-service trainings or pre-service upgrading programs. Furthermore, employability skills enable operators to prove that they can be successful with their occupation. Therefore, by following the changes in the dynamically changing labor market, machine operators must have possessed employability skills in order to stay in their work. Prospective machine operators who are going to enter the world of work should have prioritized skills in order to be recruited, so that the graduates of mechanical engineering from vocational high school (VHS) can participate successfully in the global labor market competition. Eventually, ideal graduates and machine operators have always to be ready to adapt to their work competencies in order that they have the competencies which can compete in the national and even regional ASEAN regions.

Figure 3 presents the formulation of the employability skills that are recommended to machine operators. Meanwhile, the description of the 14 employability skills that must be mastered by machine operators is presented in Table 2. Specifically and in details, the recommended framework can become a guide for machine operators in their efforts to be recruited by employers in the industry.

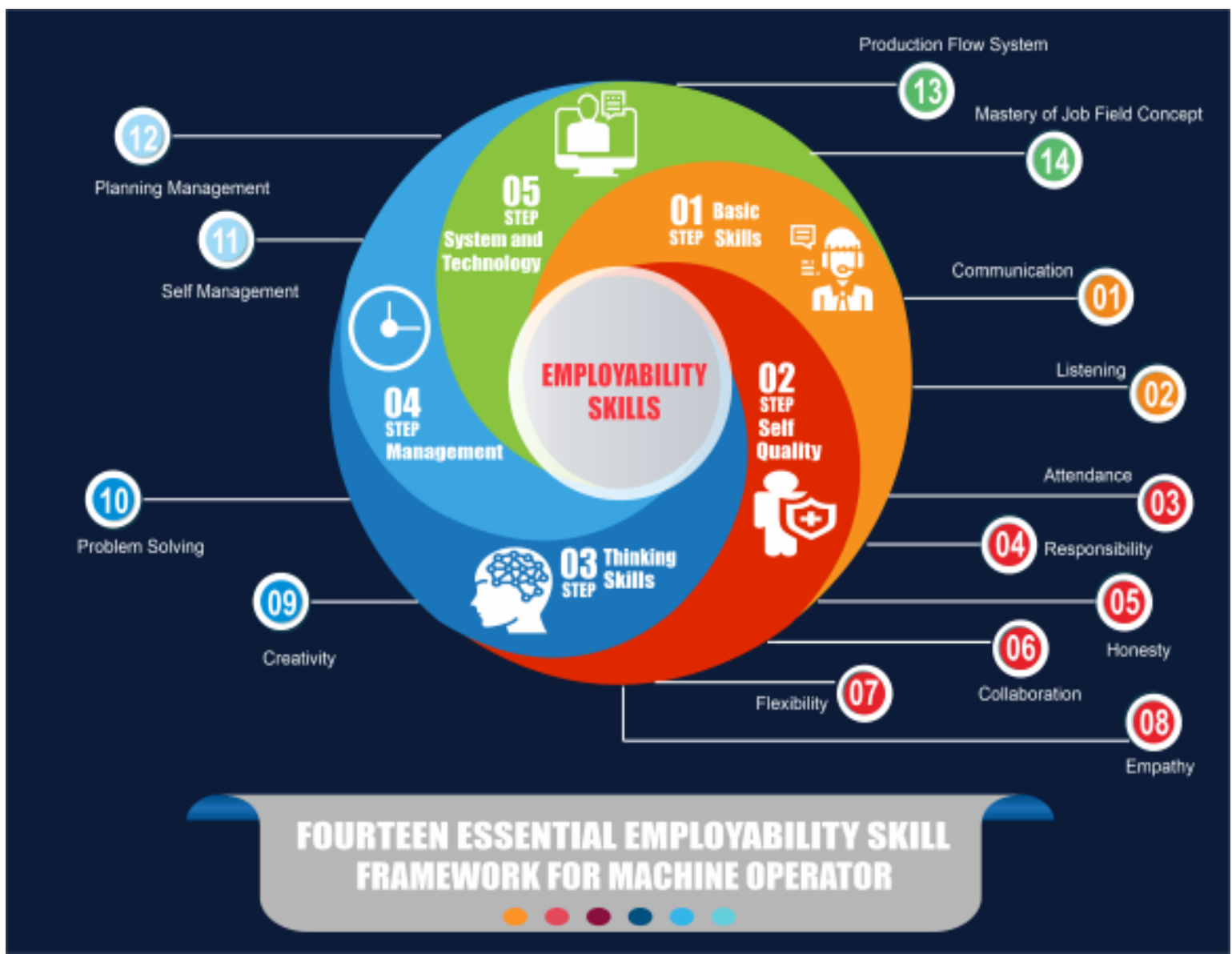

Figure 3. Model Framework of 14 Employability Skills of Machine Operators 
Table 2. Model Framework Description of 14 Employability Skills for Machine Operators

\begin{tabular}{|c|c|c|}
\hline \multicolumn{2}{|c|}{ Employability Skills } & Description \\
\hline Basic Skills & Communication & $\begin{array}{l}\text { Machine operators can deliver information clearly to } \\
\text { other machine operators, team leaders, and other } \\
\text { workers in the company as it is needed. }\end{array}$ \\
\hline & Listening & $\begin{array}{l}\text { Machine operators can listen to something carefully } \\
\text { and attentively in order to be able to analyze } \\
\text { information on the job command from team leaders and } \\
\text { supervisors. }\end{array}$ \\
\hline \multirow[t]{6}{*}{ Self Quality } & Attendance & $\begin{array}{l}\text { Machine operators can keep their discipline in } \\
\text { attendance to be able to work during the time as } \\
\text { regulated by the company. }\end{array}$ \\
\hline & Responsibility & $\begin{array}{l}\text { Machine operators can be responsible for the products } \\
\text { they have worked on, according to their own job } \\
\text { description in their own division. }\end{array}$ \\
\hline & Honesty & $\begin{array}{l}\text { Machine operators can act honestly in working under } \\
\text { any circumtances at work. }\end{array}$ \\
\hline & Collaboration & $\begin{array}{l}\text { Machine operators can work in teams or groups } \\
\text { discussing and sharing the job to make them work more } \\
\text { effectively. }\end{array}$ \\
\hline & Flexibility & $\begin{array}{l}\text { Machine operators can adapt by adjusting themselves } \\
\text { with their working environment, shown by their } \\
\text { willingness to learn. }\end{array}$ \\
\hline & Empathy & $\begin{array}{l}\text { Machine operators have empathy by helping and } \\
\text { supporting other machine operators to reach the } \\
\text { production targets. }\end{array}$ \\
\hline \multirow[t]{2}{*}{ Thinking Skills } & Creativity & $\begin{array}{l}\text { Machine operators must be creative by prioritizing } \\
\text { effective and efficient working steps in doing their job } \\
\text { without decreasing the standard quality of the } \\
\text { company's product. }\end{array}$ \\
\hline & Problem Solving & $\begin{array}{l}\text { Machine operators must be able to solve problems by } \\
\text { doing new jobs as desired by various customers' } \\
\text { orders. }\end{array}$ \\
\hline \multirow[t]{2}{*}{ Management } & Self Management & $\begin{array}{l}\text { Machine operators can manage time by being } \\
\text { discipline, shown by being on time at work, following } \\
\text { the schedule that has been established. }\end{array}$ \\
\hline & Planning Management & $\begin{array}{l}\text { Machine operators can finish the production project } \\
\text { planning according to the established deadline. }\end{array}$ \\
\hline \multirow[t]{2}{*}{$\begin{array}{l}\text { System } \\
\text { nology }\end{array}$} & $\begin{array}{l}\text { Production Flow Sys- } \\
\text { tem }\end{array}$ & $\begin{array}{l}\text { Machine operators can understand the production flow, } \\
\text { starting from raw materials to the final product (Raw } \\
\text { material-Production Process- Quality Control). }\end{array}$ \\
\hline & $\begin{array}{l}\text { Mastery of Job Field } \\
\text { Concept }\end{array}$ & $\begin{array}{l}\text { Machine operators can master the job field concept, } \\
\text { such as reading the machine engineering figures, } \\
\text { operating the measurement tools, using the hand tools } \\
\text { powerfully, operating conventional machines, and } \\
\text { operating CNC machine. }\end{array}$ \\
\hline
\end{tabular}

\section{Communication}

Communication skill is a basic skill considered the most important. Various employability skills of operators always need a good communication skill. The communication skill of machine operators is obviously different from that of other workers in general. Machine operators seldom talk to the other fellow workers because they deal with non-living things or machines, not humans.

Communication skill is an important aspect, which means that workers have to be skillful in communicating with people of different language backgrounds, and they have to be able to use various forms of communication (Wei Chan et al., 2018), at least, communication in a clear and understandable language. In the workplace, machine operators communicate more intensively with other 
fellow workers or machine operators. Every machine operator must actively communicate clearly so that there will be no misunderstanding, which can cause loses for the company. Meanwhile, communication with their employer or team leader is needed only occasionally and situational in nature. However, it does not mean that they are passive and do not communicate. This aims to maintain the ethics of good interpersonal relationships between employers and employees.

Furthermore, when a machine operator has difficulties in his job, he must be able to communicate verbally in a proper way to solve problems well (Lee \& Chin, 2017). This is important in order to support his work. Communication has to be based on honesty so that an operator is open to any problem. Some mistakes are often made by machine operators, including not communicating essential things despite their importance, for instance, a mistake or failure in production. If it continues, it will bring harm to the company.

\section{Listening}

Industries agree that listening to instructions is very important. The instruction given by an employer is usually conveyed at the beginning of work or when there is a need for operators regarding job information. Machine operators are often faced with a situation when they have to listen to instructions or orders from their superior. One form of instructions is about job description and explanation on how they have to carry out their work. At this stage, they are required to listen attentively in order that the instruction can be carried out well in accordance with the team leader's direction.

The listening skill is important for the success of machine operators. A team leader is satisfied when machine operators can prove the result of their work, which indicates that they listen to instructions well. In this way, they get feedbacks that aim to improve their work performance (Longweni \& Kroon, 2018). Listening to superiors highly empathically is with the aims that misunderstanding and misinformation will not happen, which means that machine operators understand the conversation and so they meet their team leader's expectation.

\section{Attendance}

The interview result shows that attendance can improve machine operators' career because by maintaining attendance, they show that they are productive workers, assessed from their attendance report. Managers do not like machine operators who often ask for leave permission or are absent without good reasons, and this often causes them to get heavy sanctions and expel from their job.

Attendance is often interpreted as something important for industries because it teaches machine operators to obey the regulation in the industries. Attendance, often related to presence, includes starting the work at the specified time, being at the workshop on workdays, and completing the described job responsibly. Research findings show that machine operators' superiors, such as supervisors and managers, like those who maintain their work attendance. Their routine attendance shows their good work ethics. This is supported by the findings of the research by Lindsay et al. (2014) that workers must have responsibility for their job by maintaining their attendance.

\section{Responsibility}

Other research findings show that industries appreciate the workers who have a high responsibility (Dicker et al., 2019; Potgieter \& Ferreira, 2018). In addition, operators must have a responsibility by showing totality in working, which means they can organize all works to be finished with the best results. The superior, who is the team leader or supervisor, can indirectly evaluate how machine operators work by looking at their totality and seriousness in working. This, of course, has a good impact on their career.

Other research findings prove that; managers like machine operators have a positive attitude toward and are responsible for their job (Lim et al., 2016). Being responsible in this case is being able to be relied on doing the job in accordance with specified main duties in each field or division. All responsibilities and duties of machine operators must be carried out in accordance with their 
job description. By building trust in machine operators, employers will find the greater integrity of an operator that can be built while having loyalty to the company.

Building the character of responsibility in workplace tends to be difficult. Not all machine operators find it important to do their job seriously, and there are some who work only to fulfil their obligations. Supervisors or managers need to encourage and give appreciation to good operators. Not only the appreciation in the form of rewards but also direct and useful gratitude and praises are the forms of acknowledgement of machine operators' good work. Therefore, they will have the feeling of belonging to the company and be responsible to work for the good reputation of both the company and themselves.

\section{Honesty}

The character value of honesty begins to disappear due to one's attitude. Honesty in the world of work is very important in achieving the success of workers. Honesty has a positive impact on workers because the honesty values always prevent them from various negative actions. In industries, the honesty culture reflects professionalism in working. In this case, machine operators are obliged to be honest in their work. Industries also prioritize self-quality over hard skills in the recruitment of skillful prospective machine operators. Research findings show machine operators have to possess honesty, for example when they are given a job by their supervisor, it must be done honestly. Moreover, when an operator has performed his work honestly, he can give trust to his supervisor after what he has done.

There are many instances of honesty in industries' work culture, including admitting the mistakes that have been made. The character of honesty is very important in building good reputation in workplace. It is important for machine operators to possess good reputation because it can result in the trust from their supervisor and fellow workers. On the other hand, if honesty is ignored, what will happen is that the relationship already made will be broken because it is difficult to develop since there is no trust from anyone and even the career that has been built can be destroyed.

It is a must for skillful machine operators to have integrity in their job. They should tell the truth, are honest about whatever happens, and are open-minded. In this way, the actions the do have positive impacts on the development of themselves and companies or organizations. Moreover, a machine operator can be promoted to a team leader or even a supervisor.

\section{Collaboration}

Manufacturing industries need very much operators who can collaborate in a team well. The result of the interviews shows that industries agree to prefer machine operators who can collaborate in a team well. This is not without reason because in their job description machine operators cannot work independently. In terms of responsibility, one division is interrelated with another division. However, some machine operators do not collaborate as a team. Actually, there are advantages in teamwork, one of which is in making a product, where operators may work collaboratively by sharing assembled parts to be done together, which makes the job easier.

This is in line with the research findings, which show that industries need workers who collaborate with others (Buntat et al., 2013). This is because by working in a team, all processes of work become more efficient because they can be finished simultaneously in accordance with the production target. From the management's viewpoint, managers consider team work in the workplace will also help industries' productivities and the inspiration of new ideas from group discussions. In an effective team, working in teams can also make machine operators and their fellow workers do the job from different perspectives in accordance with their background and work experience. This will be very advantageous because it can help industries to create an optimal, concrete solution.

\section{Flexibility}

The workplace environment certainly has various cultures and customs. However, cultural differences in the workplace are not a problem for workers who have good adaptability. Quickly adapting to the environment can make workers more acceptable to their work environment (Ahmed 
et al., 2012). How to adapt to the work environment can be seen from machine operators who have perseverance and high learning interests. Good machine operators do not stay in one production division. However, they can move to other divisions to learn other knowledge. The development of their employability skills can be achieved by participating in companies' training or through selfdevelopment.

Adaptation processes need self-adaptation in order to adapt to the climate of the work environment in companies. New machine operators need never-ending learning regardless of their ages. In addition, discipline with a flexible mindset and transferable skills, and dynamic adaptability with the work environment are a good key to adaptation (Bunney et al., 2015). Therefore, machine operators can show good work performance in the transition to a new environment so that they have opportunities to develop (Kamaliah et al., 2018).

\section{Empathy}

To foster a condition conducive to collaboration among workers in machine operators' environment, ideally, there is a feeling of empathy among machine operators and their supervisors. Some of the interviews and survey results show that the skills needed by workers consist of basic skills and social competence (Sermsuk et al., 2014). In the Industrial Revolution 4.0 era, it is an obligation for operators to have social skills. There are many advantages machine operators can feel when in their everyday activities they face problems which can be solved by exchanging ideas and mutually helping other machine operators. Research findings also show the best workers cannot just work alone; there need to be other people who can be a team to collaborate. The reality in the field shows that machine operators usually have to help and support other machine operators' routine work with work log, provided that the work has been finished. Therefore, the job can be worked out quickly and efficiently.

The company's success in increasing productivity must certainly start with a good sense of empathy to build better relationship with other operators. Indirectly, the personal relationship of each operator also gives a better performance. The working convenience machine operators have got will certainly give effect to the harmony among them, and it is the capital to help build relationships and pursue a better career.

\section{Creativity}

One of the measures of creativity of a machine operator is his ability to work effectively. As an example, a machine operator does his work in his own way without ignoring the quality of the product. This means that he has to save time by doing his work faster than the estimated time. Sometimes a worker does not have to follow the procedure but he can find new procedure which does not jeopardize his own safety.

This is in line with the statement that creativity is an important dimension for a worker (Yang et al., 2015). The invention of a new way to save time very much affects the selling price of a product; the longer the time spent on making it, the higher the price will be. Therefore, an operator is allowed to find a new way as long as the product is good and the same, and it does not jeopardize his own safety. For example, the machinery parameter process can be done in a shorter time by burying it deeper, faster than spindle rotation.

\section{Solving Problems}

In their workplace, machine operators are always faced with concrete problems. This is important for them so that they can solve the problems in their work well. Research findings prove that machine operators must work in multicultural environments such as manufacturing industries (Spinks et al., 2007). A multicultural environment such as manufacturing industries is very complex, starting from problems of cultural differences, which certainly trigger conflicts among the workers. Therefore, machine operators must solve their problems by themselves, and differences in individuals' opinions must be responded to wisely.

In addition, when receiving various orders from customers, such as different materials, complex shapes, and meticulous tolerance sizes, a machine operator must scrutinize how to fulfill the 
various orders. There needs to be a critical reflection on developing an idea to play an active role in solving the problem (de Schepper \& Sotiriadou, 2018). Most importantly, a machine operator must be able to analyze an effective way to make a product according to consumers' desire. In this way, the product is in accordance with consumers' desire and the production target is achieved.

\section{Self-Management}

For a worker, especially a machine operator, self-management is not an additional skill anymore; it is a skill that is essential in nature. Research findings show the need for discipline to improve a company's advancement development (Boahin \& Hofman, 2013). One of the ways that a company can develop well is by having machine operators manage themselves with their discipline of time in working. Therefore, there needs to be a binding rule to discipline work time.

Some companies consider Self-management skills as the most important indicator, and many industries look for them (Sermsuk et al., 2014). Supervisors and managers consider the specific self-management skill needed is time management skill. The most essential thing is time, i.e., how machine operators can manage time well. For example, the obligation of coming to work and going home on time, i.e., neither coming late nor going home earlier. Although it looks simple, it is often difficult for some operators to do. By coming to the office and going home on time, they get used to finishing their job in accordance with the deadline.

\section{Management of Planning}

Another important attribute is planning and works performance improvement (Bridgstock, 2009). Good planning for machine operators gives a focused direction to achieve goals according to the plan made. In addition, with the scheduled plan, machine operators can know what objective must be achieved and what must be done to achieve it. Furthermore, the machine operators who have planning management ability can plan and organize the time regularly so that they can accomplish the job and prioritize which job must be finished first.

Machine operators should determine the main and earlier-to-complete work to manage the time easily. Specific job priorities will help machine operators to be more disciplined and will minimize the risk of work being neglected. With the target schedule, they can quickly finish the work by maximizing the available time. In addition, a target schedule will encourage them to maximize their ability (de Guzman \& Choi, 2013).

\section{Production Flow System}

There is a production flow from raw materials to finished materials in the manufacturing process. It is very important for machine operators to know the production flow system from raw material - production process - quality control (Drange et al., 2018). The production process function can make a raw metal product to become a value-added product. Technically in the field, machine operators have to understand the overview of production flow because it impacts the quality of the product. By understanding a production flow, they can estimate the product they made to be assembled to the next section.

Research findings show that by understanding the production flow, for example, in the aviation industries, machine operators understand the detailed production flow. The product can be customized according to its function, and if it is fixed in the vital part, it will take a high tolerance. On the other hand, if it is fixed in the part which is not vital and just a compliment, tolerance can be reduced, and fineness can be adjusted. For this rationalization, production operators can save production time, and production is quicker and more efficient so that it will be faster than the production target (Okunuga \& Ajeyalemi, 2018).

\section{Mastery of Job Field Concept}

The mastery of the job field concept will impact the ease of getting a job and staying in the job (Ćurić Dražić et al., 2018). A machine operator must be able to master his job field concept. The field concept of machine operators includes manufacturing. More specifically, they must oper- 
ate production machinery, design and examine a product, and operate computer numerically controlled (CNC) machine (Markes, 2006; Motyl et al., 2017). The qualitative finding also shows that machine operators must be able to use manual tools and powered tools, use precision mechanical measurement instruments, operate conventional machines, and operate $\mathrm{CNC}$ machines.

The important job field for machine operators is the mastery of the basic concept of machine operators' field. Therefore, what must be emphasized is the mastery of concept first, and then they just develop themselves in their workplace. In addition, their understanding of machinery logic related to functions, actions, and machine instruction is deepened. Furthermore, they have to increase their work experience by doing many practices, because by doing so, they will get used to their job and thus increase their technical mastery.

Anticipating technological change, machine operators must have sensitivity by adapting themselves to new jobs with good learning interests. Therefore, despite the rapid change in technology, they can be open and learn to change employability skills. For this reason, their flexibility is highly required. In this way, supervisors can appreciate the performance supporting sustainable technological development (Ali et al., 2018).

\section{CONCLUSION}

The research findings show that there are 14 attributes of essential employability skills which serve as the framework for machine operators. The employability skills are identified and ordered according to the priority by manufacturing industries of metal and machinery as follows: (1) basic skills: communicating, listening; (2) self-quality: attendance, collaboration, responsibility, honesty, flexibility, empathy; (3) thinking skills: creativeness, problem solving; (4) management: self-management, planning; (5) system and technology: production flow system, mastery of job field concept, and production flow system. Overall, industries prioritize basic skills as the main obligation and self-quality as the priority for recruitment. Furthermore, thinking skill, managerial skill, and system and technology skill will be developed later in the workplace.

The implication of this study is that, for the stakeholders of manufacturing industries of metal and machinery, employability skills can be the reference for their companies when recruiting prospective machine operators and that evaluating machine operators' work performance is important to support the long-term sustainability of their industries. The framework of employability skills can become the basis for practical arrangements for the curriculum or competency development programs at mechanical engineering vocational high schools. This research finding can help teachers to identify the gap between industries and schools. Therefore, the understanding of employability skills can contribute to the career development of their graduates, in order to be able to compete in the dynamically changing labor market.

\section{REFERENCES}

Ahmed, F., Capretz, L. F., Bouktif, S., \& Campbell, P. (2012). Soft skills requirements in software development jobs: A cross-cultural empirical study. Journal of Systems and Information Technology, 14(1), 58-81. https://doi.org/10.1108/13287261211221137

Ali, A., Murphy, H. C., \& Nadkarni, S. (2018). Hospitality employers' perceptions of technology for sustainable development: The implications for graduate employability. Tourism and Hospitality Research, 18(2), 131-142. https://doi.org/10.1177/1467358416636929

Babbie, E. R. (2007). The practice of social reserch. Wadswoth/Thomson.

Boahin, P., \& Hofman, A. (2013). A disciplinary perspective of competency-based training on the acquisition of employability skills. Journal of Vocational Education and Training, 65(3), 385-401. https://doi.org/10.1080/13636820.2013.834954

Bridgstock, R. (2009). The graduate attributes we've overlooked: Enhancing graduate employability through career management skills. Higher Education Research and Development, 28(1), 31-44. https://doi.org/10.1080/07294360802444347 
Bukit, M. (2014). Strategi dan inovasi pendidikan kejuruan (dari kompetensi ke kompetisi) (D. Lesmaya (ed.)). Alfabeta, CV.

Bunney, D., Sharplin, E., \& Howitt, C. (2015). Generic skills for graduate accountants: The bigger picture, a social and economic imperative in the new knowledge economy. Higher Education Research and Development, 34(2), 256-269. https://doi.org/10.1080/07294360.2014.956700

Buntat, Y., Jabor, M. K., Saud, M. S., Mansor, S. M. S. S., \& Mustaffa, N. H. (2013). Employability skills element's: Difference perspective between teaching staff and employers industrial in Malaysia. Procedia - Social and Behavioral Sciences, 93(1990), 1531-1535. https://doi.org/10.1016/j.sbspro.2013.10.077

Creswell, J. W. (2009). Research design: Quaitative, quantitative, and mixed method approaches (3rd ed.). SAGE publication.

Ćurić Dražić, M., Petrović, I. B., \& Vukelić, M. (2018). Career ambition as a way of understanding the relation between locus of control and self-perceived employability among Psychology students. Frontiers in Psychology, 9(SEP), 1-8. https://doi.org/10.3389/fpsyg.2018.01729

de Guzman, A. B., \& Choi, K. O. (2013). The relations of employability skills to career adaptability among technical school students. Journal of Vocational Behavior, 82(3), 199207. https://doi.org/10.1016/j.jvb.2013.01.009

de Schepper, J., \& Sotiriadou, P. (2018). A framework for critical reflection in sport management education and graduate employability. Annals of Leisure Research, 21(2), 227-245. https:// doi.org/10.1080/11745398.2017.1336107

Dicker, R., Garcia, M., Kelly, A., \& Mulrooney, H. (2019). What does 'quality' in higher education mean? Perceptions of staff, students and employers. Studies in Higher Education, 44(8), 1425-1441. https://doi.org/10.1080/03075079.2018.1445987

Drange, I., Bernstrøm, V. H., \& Mamelund, S.-E. (2018). Are you moving up or falling short? An inquiry of skills-based variation in self-perceived employability among Norwegian employees. Work, Employment and Society, 32(2), 387-406. https://doi.org/10.1177/095001 7017749720

Husain, M. Y., Mokhtar, S. B., Ahmad, A. A., \& Mustapha, R. (2010). Importance of employability skills from employers' perspective. Procedia - Social and Behavioral Sciences, 7(2), 430-438. https://doi.org/10.1016/j.sbspro.2010.10.059

International Labour Organization. (2018). Asia-Pacific employment and social outlook: Advancing decent work for sustainable development. Regional Economic and Social Analysis Unit of International Labour Organization. https://www.ilo.org/wcmsp5/groups/public/---asia/---robangkok/---sro-bangkok/documents/publication/wcms_649885.pdf

Ismail, S., \& Mohammed, D. S. (2015). Employability skills in TVET curriculum in Nigeria Federal Universities of Technology. Procedia - Social and Behavioral Sciences, 204(November 2014), 73-80. https://doi.org/10.1016/j.sbspro.2015.08.111

Kamaliah, S., Roslan, S., Bakar, A. R., \& Ghiami, Z. (2018). The effect of supervised work experience on the acquisition of employability skills among Malaysian students. Higher Education, Skills and Work-Based Learning, 8(4), 354-364. https://doi.org/10.1108/HES WBL-05-2016-0028

Lee, C.-C., \& Chin, S.-F. (2017). Engineering students' perceptions of graduate attributes: Perspectives from two educational paths. IEEE Transactions on Professional Communication, 60(1), 42-55. https://doi.org/10.1109/TPC.2016.2632840

Lim, Y.-M., Lee, T. H., Yap, C. S., \& Ling, C. C. (2016). Employability skills, personal qualities, and early employment problems of entry-level auditors: Perspectives from employers, 
lecturers, auditors, and students. Journal of Education for Business, 91(4), 185-192. https:// doi.org/10.1080/08832323.2016.1153998

Lindsay, S., Adams, T., Sanford, R., McDougall, C., Kingsnorth, S., \& Menna-Dack, D. (2014). Employers' and employment counselors' perceptions of desirable skills for entry-level positions for adolescents: How does it differ for youth with disabilities? Disability \& Society, 29(6), 953-967. https://doi.org/10.1080/09687599.2013.874330

Longweni, M., \& Kroon, J. (2018). Managers' listening skills, feedback skills and ability to deal with interference: A subordinate perspective. Acta Commercii, 18(1), 1-12. https://doi.org/ 10.4102/ac.v18i1.533

Markes, I. (2006). A review of literature on employability skill needs in engineering. European Journal of Engineering Education, 31(6), 637-650. https://doi.org/10.1080/030437906009 11704

McLean, M., Murdoch-Eaton, D., \& Shaban, S. (2013). Poor English language proficiency hinders generic skills development: A qualitative study of the perspectives of first-year medical students. Journal of Further and Higher Education, 37(4), 462-481. https://doi.org/10.1080/ 0309877X.2011.645461

Motyl, B., Baronio, G., Uberti, S., Speranza, D., \& Filippi, S. (2017). How will change the future engineers' skills in the industry 4.0 framework? A questionnaire survey. Procedia Manufacturing, 11(June), 1501-1509. https://doi.org/10.1016/j.promfg.2017.07.282

Nair, C. S., Patil, A., \& Mertova, P. (2009). Re-engineering graduate skills - A case study. European Journal of Engineering Education, 34(2), 131-139. https://doi.org/10.1080/03043 790902829281

National Professional Certification Agency. (2017). KKNI II teknik pemesinan. National Professional Certification Agency.

Okunuga, R. O., \& Ajeyalemi, D. (2018). Relationship between knowledge and skills in the Nigerian undergraduate chemistry curriculum and graduate employability in chemical-based industries. Industry and Higher Education, 32(3), 183-191. https://doi.org/10.1177/09504 22218766913

Potgieter, I. L., \& Ferreira, N. (2018). Personality preference facets and self-regulatory employability of human resource professionals. South African Journal of Psychology, 48(1), 142-154. https://doi.org/10.1177/0081246316685934

Rowley, C. (2014). Student and employer perceptions of the importance of entry-level employability skills. California State University. http://hdl.voced.edu.au/10707/326274

Sermsuk, S., Triwichitkhun, D., \& Wongwanich, S. (2014). Employment conditions and essential employability skills required by employers for secondary school graduate. Procedia - Social and Behavioral Sciences, 116, 1848-1854. https://doi.org/10.1016/j.sbspro.2014.01.482

Sisodia, S., \& Agarwal, N. (2017). Employability skills essential for healthcare industry. Procedia Computer Science, 122, 431-438. https://doi.org/10.1016/j.procs.2017.11.390

Spinks, N., Silburn, N. L. J., \& Birchall, D. W. (2007). Making it all work: The engineering graduate of the future, a UK perspective. European Journal of Engineering Education, 32(3), 325-335. https://doi.org/10.1080/03043790701278573

Stoner, G., \& Milner, M. (2010). Embedding generic employability skills in an accounting degree: Development and impediments. Accounting Education, 19(1-2), 123-138. https://doi.org/ $10.1080 / 09639280902888229$

Tjiptoherijanto, P. (2001). Proyeksi penduduk, angkatan kerja, tenaga kerja, dan peran serikat pekerja dalam peningkatan kesejahteraan. Majalah Perencanaan Pembangunan, 23, 1-10. https://www.bappenas.go.id/id/data-dan-informasi-utama/makalah/artikel-majalah-perencana 
an/edisi-23-tahun-2001/proyeksi-penduduk-angkatan-kerja-tenaga-kerja-dan-peran-serikatpekerja-dalam-peningkatan-kesejahteraan---oleh-prijono-tjiptoherijanto/

Wei Chan, S., F. Ahmad, M., Zaman, I., \& Shin Ko, W. (2018). Employers' perception on important employability skills in the manufacturing industry. International Journal of Engineering \& Technology, 7(2.29), 170. https://doi.org/10.14419/ijet.v7i2.29.13311

Wibawa, B. (2005). Pendidikan teknologi dan kejuruan (manajemen dan impelementasi di era otonomi). Kertajaya Duta Media.

Wickramasinghe, V., \& Perera, L. (2010). Graduates', university lecturers' and employers' perceptions towards employability skills. Education + Training, 52(3), 226-244. https://doi. org/10.1108/00400911011037355

Yang, H., Cheung, C., \& Fang, C. C. (2015). An empirical study of hospitality employability skills: Perceptions of entry-level hotel staff in China. Journal of Hospitality \& Tourism Education, 27(4), 161-170. https://doi.org/10.1080/10963758.2015.1089510

Zaharim, A., Yusoff, Y. M., Omar, M. Z., Mohamed, A., \& Muhamad, N. (2009). Engineering Employability Skills Required By Employers In Asia. EDUCATION'09: Proceedings of the 6th WSEAS International Conference on Engineering Education, July, 195-201. https://doi. org/10.5555/1864130.1864169 